\title{
Richard Kilvington and the Theory of Obligations *
}

\section{Stephen Read}

\begin{abstract}
Kretzmann and Spade were led by Richard Kilvington's proposed revisions to the rules of obligations in his discussion of the $47^{\text {th }}$ sophism in his Sophismata to claim that the purpose of obligational disputations was the same as that of counterfactual reasoning. Angel d'Ors challenged this interpretation, realising that the reason for Kilvington's revision was precisely that he found the art of obligation unsuited to the kind of reasoning which lay at the heart of the sophismatic argument. In his criticism, Kilvington focussed on a technique used by Walter Burley to force a respondent to grant an arbitrary falsehood and similar to Lewis and Langford's famous defence of ex impossibili quodlibet. Kilvington observes that just as in obligational disputation, one may be obliged to grant a false proposition and deny a true one, so in counterfactual reasoning one may be obliged to doubt a proposition whose truth or falsity one knows, on pain of contradiction.
\end{abstract}

Keywords: obligations, sophisms, ex impossibili quodlibet, Kilvington, Burley

We owe an immense debt to Angel d'Ors for his extensive and persistent research into identifying the real author of the famous Tractatus, for centuries (as he showed) wrongly attributed to Pope John XXI. I recall with pleasure the occasion in 1997 on which some of us visited the birthplace of the true Peter of Spain, Lizarra (Estella), where the mayor dedicated a street (a very short street, but a whole street, nonetheless) to one of the foremost logicians of the middle ages. As Mark Twain might have said, scholars, that is, one scholar in particular,

*For Studies on the History of Logic: A Volume in Honour of Angel d'Ors, edited by María Cerezo and Paloma Pérez-Ilzarbe. 
Angel, has shown that the logical works of Peter of Spain were not written by him but by another man, a Basque, with the same name.

Angel d'Ors also made significant contributions to our understanding and interpretation of medieval logic, in particular, to the debate over the validity of the spread law, ex impossibili quodlibet, and to the correct account of the development of the theory of obligations. The current paper tackles these two issues, and benefits considerably from d'Ors's incisive reflections.

The distinctive contribution of medieval logic in the Latin West began in the twelfth century in response to the rediscovery of the bulk of Aristotle's logical writings, hitherto known there largely through the rather elementary and simplistic writings of Boethius. Most stimulating seems to have been the circulation of Aristotle's treatise De Sophisticis Elenchis, and Book VIII of the Topics. The latter contains his discussion of disputation, arguably the inspiration for that most original and initially puzzling genre of medieval logical treatises, those on obligations. Supposition theory, appellation and insolubles all puzzled early scholars of medieval logic in the nineteenth and twentieth centuries, but none so much as these disputations and dialogues between opponent and respondent with their positing, accepting, granting, denying, doubting and casus in the treatises on obligations.

One of the most original, exciting, and as d'Ors showed, misleading proposals for the interpretation of the game of obligations was that put forward by Norman Kretzmann and developed by Paul Spade, that it should be understood as a logic of counterfactuals. Kretzmann and Spade seized on some remarks in Richard Kilvington's Sophismata to support their claim. As the title shows, Kilvington's Sophismata is not a treatise on obligations, but a collection of 48 sophisms, 44 being about logical problems in physics, the final four raising logical puzzles in the theory of knowledge. Richard Kilvington, along with Thomas Bradwardine, was one of the initiators of a movement which came in retrospect to be called the "Oxford Calculators". Its members signalled the first real advance 
over Aristotle in the theory of dynamics, to some extent anticipating the epochmaking insights of the seventeenth century. The connection with obligations is that in Kilvington's treatise, as in Bradwardine's Insolubilia which preceded it by only a few years, we find a constant use of the terminology of logical obligations. ${ }^{1}$ That the usage was so endemic and, as d'Ors argues, ${ }^{2}$ found its way into inappropriate contexts, supports the thesis that obligations were extensively used as logical exercises for pedagogical purposes.

But Kretzmann and Spade fasten on Kilvington's remarks on obligations in his treatment of Sophism 47 to argue for a different rationale for obligations, namely, "that the aim of obligational disputation was the same as the aim of counterfactual reasoning generally: to investigate conditions in a world that is different from the actual world in one respect (or in a few respects) but otherwise as much like the actual world as possible." ${ }^{3}$ The sophism focuses on the proposition 'You know that the king is seated', attempts, as is common practice in sophismatic treatises, to argue both for and against the sophismatic sentence, and finally proposes a solution to dispel the apparent contradiction. The arguments, and the solution, however, employ the obligational language of granting, denying and doubting. There are several species of obligations, the primary one being positio. In every obligation, as already noted, there are two agents, the opponent and the respondent. The opponent starts by outlining a casus, or hypothesis, a background situation against which the obligation will take place, and in possible positio, puts forward a proposition, the positum, normally false both in the casus and in fact (if not, the positio will be less

\footnotetext{
${ }^{1}$ See, e.g. Mikko Yrjönsuuri, Obligationes: $14^{\text {th }}$ Century Logic of Disputational Duties (Acta Philosophica Fennica 55, 1994), p. 108.

${ }^{2}$ Angel d'Ors, 'Tu scis regem sedere (Kilvington, S47[48])', Anuario filosófico, 24 (1991), pp. 667.

${ }^{3}$ N. and B.E. Kretzmann, The Sophismata of Richard Kilvington: Introduction, Translation and Commentary (Cambirdge UP,1990), p. 344. (All citations in English from Kilvington are from this translation.)
} 
interesting and perhaps less challenging). The respondent should accept the positum if it nonetheless could be true in the casus, after which the opponent presents a succession of propositions (proposita), to each of which the respondent must reply either by granting it, or by denying it, or by doubting it, according to strict rules. These rules vary between different authors. The set of rules to which Kilvington takes exception seem to be those found in one of the most detailed of the obligational treatises which have survived, that due to Walter Burley, composed some twenty years before Kilvington was writing, also in Oxford, and indeed just across the street from Kilvington's college of Oriel, at Merton College. According to Burley, one must first decide whether a particular propositum is relevant (pertinens) or not, that is, whether it either follows from, or is inconsistent with, the collection of propositions consisting of the positum together with any propositions previously granted and the contradictories of any previously denied. If it follows from them, it is said to be pertinens sequens, and should be granted, if inconsistent with them, it is said to be pertinens repugnans, and should be denied. Otherwise, it is irrelevant (impertinens), and should be granted if true according to the casus, denied if false according to the casus, and should be doubted if the casus leaves it indeterminate. A common example of the last sort, left indeterminate by the casus, is whether the king is seated or not. It is striking that Sophism 47 posits at the outset that you know whether the king is seated or not. But it does not specify which.

What results is a sequence of responses, granting, denying and doubting the proposita, and thereby a collection of propositions, those granted and the contradictories of those denied. The subtlety and complexity of the result stems from the fact that there are two separate criteria for inclusion in the set, one depending on the logical relation to previous responses, the other on what was laid down in the casus. Nonetheless, it is arguable that the respondent has a winning strategy: provided the positum is consistent with the casus (and if not, the respondent should not have accepted it), care by the respondent can ensure 
that the resulting set will also be consistent. ${ }^{4}$ Thus if the respondent contradicts himself, that is, both grants and denies the same proposition, or grants something contradictory, he really has made an error, and is rightly said by Burley's rules to have erred and to lose the game. The obligation ends either when this happens, or after a pre-agreed time, after which the respondent's performance is discussed and evaluated.

Sophism 47 starts with a casus, in this case, that if the king is seated, you know he is, and if he is not seated, you know that too. Then two examples of obligational dialogue are given-for the first, see Figure 1.

0. [arbitrary]

1. Either the king is seated or he is not

2. You know that the king is seated or you know that the king is not seated

3. You do not know that the king is not seated

4. You know that the king is seated
Accepted (the positum)

Granted (law of excluded middle)

Granted (follows from 1. by the casus)

Granted (irrelevant and true)

Granted (follows from 2. and 3.)

Figure 1: Proof of the Sophism

\footnotetext{
${ }^{4}$ See, e.g., Catarina Dutilh Novaes, Formalizing medieval logical theories: suppositio, consequentiae and obligationes (Dordrecht: Springer, 2007), p. 161.
} 
As Stump observes, ${ }^{5}$ the obligation has a somewhat unusual form, since it is really a sophism rather than an obligation, in that there does not seem to be a positum, or perhaps the positum is arbitrary, as we will see shortly. Step 1 is implicit, being a law of logic, and the actual reasoning starts at line 2, which follows logically from the casus. Line 3 is granted since what we noted is standard doctrine, that you do not know whether the king is seated or not, is not affected by the casus. The sophism (that is, the sophistic proposition) consequently follows by the rule nowadays known as Disjunctive Syllogism or as Modus Tollendo Ponens:

"The sophisma is proved in the following way. You know that the king is seated or you know that the king is not seated, but you do not know that the king is not seated; therefore, you know that the king is seated. The major is evident by the hypothesis, and the minor is evident because it is a true nonincompatible. That is evident, for these are not incompatible: 'If the king is seated, you know that the king is seated; and if the king is not seated, you know that the king is not seated' and 'You do not know that the king is not seated'. (p. 124)

However, Kilvington proceeds to give a very similar obligation which disproves the sophism. See Figure 2.

\footnotetext{
${ }^{5}$ Eleonore Stump, 'Obligations: From the Beginning to the Early Fourteenth Century', in Cambridge History of Later Medieval Philosophy, eds. N. Kretzmann, A. Kenny, and J. Pinborg (Cambridge University Press, 1982), p. 329. Cf. d'Ors, 'Tu scis regem sedere (Kilvington, S47[48]', p. 59 n. 26.

6 "Tunc probatur sophisma sic. Tu scis regem sedere vel tu scis regem non sedere, sed tu non scis regem non sedere; igitur tu scis regem sedere. Maior patet per casum, et minor patet quia est vera non repugnans. Quod patet, nam ista non repugnant: 'Si rex sedet, tu scis regem sedere; et si rex non sedet, tu scis regem non sedere' et 'Tu non scis regem non sedere'. Richard Kilvington, The Sophismata of Richard Kilvington, eds. N. Kretzmann and B.E. Kretzmann (Oxford University Press for the British Academy, 1990), p. 126. (All citations in Latin from Kilvington are from this edition.)
} 
0. [arbitrary]

1. Either the king is seated or he is not

2. You know that the king is seated or you know that the king is not seated

3'. You do not know that the king is seated

4'. You know that the king is not seated
Accepted (the positum)

Granted (law of excluded middle)

Granted (follows from 1. by the casus)

Granted (irrelevant and true)

Granted (follows from 2. and $3^{\prime}$.)

Figure 2: Disproof of the Sophism

Actually, this is not a disproof of the sophismatic proposition, so much as a proof of something incompatible with and contrary to it. As we said, you do not know that the king is seated nor do you know that the king is not seated, so both are false. But we can prove, it seems on the basis of the casus, both that you know he is and that you know he is not. The problem is not that we have proved something false, as that we have proved two things which are incompatible. Which is right?-neither, as Kilvington will say (p. 132): you do not know either of them, so you should express doubt both about his being seated and about his not being seated.

What is notable about the whole sophism is that, as d'Ors noted, ${ }^{7}$ what Kilvington observes is that the rules of obligation are not really appropriate to his task, which is to explore the counterfactual consequences of the casus, and that Kretzmann and Spade went astray in reading Kilvington's comments as revealing

${ }^{7}$ D'Ors, 'Tu scis regem sedere (Kilvington, S47[48]', p. 72. 
the purpose of obligations, possibly after Kilvington's revision, to be the articulation of counterfactual reasoning:

"[Kilvington] has assigned [the Art of Obligations] a distinct purpose and, in doing so, has changed the nature of it. It is for this reason, in my opinion, that it would be more correct to talk about not simply a reform of the Art of Obligations but the founding of a new Art, which could stand alongside it or perhaps replace it."

Kilvington is not proposing to revise the rules of obligations. He is pointing out that we need to deal with irrelevant propositions differently from the way the obligational rules dictate-indeed, effectively, to treat those propositions as relevant after all. Rather than infer, as Kretzmann did in the passage cited above, "that the aim of obligational disputation was the same as the aim of counterfactual reasoning generally," we should infer from Kilvington's rejection of the obligational rules as unfit for counterfactual reasoning that this was not their aim at all.

We will come to Kilvington's revision shortly. First, we should consider further the fact that the obligational reasoning given by Kilvington in the proof and disproof of the sophism seems to lack a positum. We should not think, as it seems some have done ${ }^{9}$ that the positum and casus are identical, or that casus and positum can play the same role. Better to think of the positum as arbitrary.

\footnotetext{
${ }^{8}$ D'Ors (loc.cit.): “... le ha asignado un fin distinto, y, con ello, ha cambiado su naturaleza. Por esta razón, en mi opinión, habria que hablar, mas que de una reforma del Arte de las Obligaciones, de la constitución de un nuevo Arte, que pudo convivir con aquel, o tal vez reemplazarle."

${ }^{9}$ Stump, 'Obligations', p. 329; Kretzmann, The Sophismata of Richard Kilvington: Introduction, Translation and Commentary, p. 330. Cf. d'Ors, 'Tu scis regem sedere (Kilvington, S47[48]', p. 65 n. 35.
} 
Another possibility, which d'Ors moots (loc.cit.), is that Kilvington is here thinking in terms not of positio but of the species of obligation called sit verum (or rei veritas). Sara Uckelman makes a strong case that, at least in some obligations treatises, sit verum does model counterfactual reasoning. ${ }^{10}$ In an early $13^{\text {th }}$-century treatise, Obligationes Parisienses, ${ }^{11}$ irrelevant propositions in sit verum are evaluated as if what was supposed to be true were indeed true. Then Kilvington's hypothesis (that if the king is seated, you know that the king is seated, and if the king is not seated, you know that the king is not seated) would not be the casus, but the object of sit verum. This would connect closely with the fact that in obligations treatises contemporary with Kilvington, sit verum is often described as specifying what the respondent knows, does not know or doubts. ${ }^{12}$ However, the fact that Kilvington refers (as we will see shortly) to the "common doctrine" for irrelevant propositions as contrasting with such a rule indicates that he is not in fact thinking in these terms.

For it becomes clear as Kilvington's discussion of the sophism proceeds that his real target is a form of reasoning found in one of Burley's rules. Burley writes:

\footnotetext{
${ }^{10} \mathrm{~S}$. Uckelman, 'Sit verum and counterfactual reasoning', typescript.

${ }^{11}$ See L.M. de Rijk, 'Some Thirteenth Century Tracts on the Game of Obligation II', Vivarium 13 (1975), 22-54.

${ }^{12}$ See, e.g., G. de Occam, Summa Logicae (Opera Philosophica I), eds. P. Boehner, G. Gal, S. Brown (St. Bonaventure, NY: Franciscan Institute, 1974), III-3, ch. 45; Walter Burley, "It is usually said that sit verum creates an obligation on a state of mind, and since states of mind are of three kinds, namely, the state of knowledge, of doubt and of ignorance, this obligation is of three kinds, either through a verb of knowing, or through a verb of doubting, or through a verb if ignorance. For example, 'Let it be true that you know you are running', or 'Let it be true that you doubt you are running'." See Romuald Green, An Introduction to the Logical Treatise De Obligationibus, With Critical Texts of William of Sherwood [?] and Walter Burley, Ph.D. dissertation (Katholieke Universiteit Leuven, 1963), vol. II, pp. 94-5.
} 
"When a false contingent proposition is granted, one can prove any false proposition compatible with it." ${ }^{13}$

He gives two ways to construct an obligation to this end. The first is given in Figure 3. Kilvington complains (p. 127):

"Thus I say-as regards a familiar example so that it may be understood more easily - that when 'You are in Rome' has been posited, it is not the case that anything false that is compossible with it can be proved, such as 'You are a bishop', and the like."14

0. You are in Rome

Accepted (the unstated casus confirms that you are not in Rome)

1. You are not in Rome or you are a bishop Granted (irrelevant, but true because you are not in Rome)

2. You are a bishop Granted (follows from 0. and 1.)

Figure 3: Proof of Burley's Rule

\footnotetext{
${ }^{13}$ Walter Burley, 'Obligations (Selections)', in N. Kretzmann and E. Stump, Cambridge Translations of Medieval Philosophical Texts vol. 1: Logic and the Philosophy of Language (Cambridge University Press, 1988), 369-412, §3.61, p. 391: "Alia regula est ista: posito falso de contingenti, contingit probare quodlibet falsum sibi compossibile." Green, An Introduction to the Logical Treatise De Obligationibus, With Critical Texts of William of Sherwood [?] and Walter Burley, vol. II, p. 57.

14 "Unde dico—in communi exemplo, ut facilius intelligatur—quod posita ista 'Tu es Romae', non contingit probare aliquod falsum sibi compossibile, ut istam: 'Tu es episcopus', et similia." (p. 130)
} 
Kilvington then proceeds to take Burley's second proof apart, which differs from the first in replacing the propositum at line 1 with "You are in Rome" and "You are a bishop" are alike' (in truth-value, or perhaps modal status ${ }^{15}$ ). But as d'Ors emphasizes ${ }^{16}$ the reasoning in Kilvington's sophism is modelled on Burley's first proof.

If we replace the particular propositions in Burley's first proof with schematic variables, we can see that what we have here is an instance of a famous proof of ex falso quodlibet. For as Burley says, given any false (contingent) proposition, we can prove any other (false) proposition-indeed, given any false proposition (or any pair of contradictory propositions-or indeed, any impossible proposition), we can prove any other proposition whatever. The proof was famously used by Lewis and Langford to rebut objections to strict negative paradox: ${ }^{17}$

"The one serious doubt ... concerning the adequacy of Strict Implication to the problems of deduction in general arises from the fact that strict implication has its [own] paradoxes ... 'If $p$ is impossible, then $p$ strictly implies any proposition $q$ '; and ... 'If $q$ is necessary, then any proposition $p$ strictly implies $q^{\prime} . "$

Their response (p. 250) to the first "paradox" is to deduce $q$ from ' $p$ and not- $p$ ', arguing that any impossible proposition is equivalent to some such conjunction: assume ' $p$ and not- $p$ ' is true; then $p$ is true, so ' $p$ or $q$ ' is true; and 'not- $p$ ' is also true; so $q$ is true. That is, if $p$ is false, then assuming $p$, we have ' $p$ or $q$ ' from the assumption, and 'not- $p$ ' by hypothesis, so $q$, by Disjunctive Syllogism.

\footnotetext{
${ }^{15}$ See Kretzmann, The Sophismata of Richard Kilvington: Introduction, Translation and Commentary, p. 336.

${ }^{16}$ D'Ors, 'Tu scis regem sedere (Kilvington, S47[48]', p. 63.

${ }^{17}$ C.I. Lewis and C.H. Langford, Symbolic Logic (New York: The Century Co., 1932), p. 248.
} 
Aristotle is often understood as claiming in Prior Analytics II 15 that only falsehoods can follow from contradictory, or even contrary, premises, at least syllogistically. Whether or not this is the right interpretation of that chapter, the above argument, and the claim that anything follows from contradictory or impossible premises, seems to have been an innovation made in the twelfth century. ${ }^{18}$ It is the basis of Burley's rule: suppose (the casus) that $p$ is false. Posit $p$, then propose 'not- $p$ or $q$ '-granted (irrelevant and true). Then propose $q-$ granted as pertinens sequens, following from $p$ and 'not- $p$ or $q$ '. Thus ad impossibile ( $p$ and not- $p$ ) sequitur quodlibet $(q)$.

Like Lewis and Langford, d'Ors thinks that negative strict paradox is a putative counterexample to the claim that an argument is valid if and only if it is impossible that things are as the premises signify and not as the conclusion signifies ${ }^{19}$ - the account adopted by Buridan, ${ }^{20}$ at least given Buridan's caveat that 'as ... signifies' must not be taken literally but must be spelled out in terms of supposition. ${ }^{21}$ But d'Ors finds the above argument, rehearsed by Buridan in conclusion 7 of Book I of his Treatise on Consequences (p. 37) less convincing. Indeed, d'Ors claims that the argument is circular. ${ }^{22}$ The problematic step is the claim that any impossibility is equivalent to, or at least entails, an explicit contradiction. Buridan gives the argument in Conclusion 6: suppose $p$ is impossible. Then $p$ and 'not- $p$ ' entail the explicit contradiction ' $p$ and not- $p$ '. But if

\footnotetext{
${ }^{18}$ See C. Martin, 'William's machine', Journal of Philosophy 83 (1986), pp. 564-72.

${ }^{19}$ Angel d'Ors, 'Ex impossibili quodlibet sequitur (John Buridan)', in Argumentationstheorie. Scholastische Forschungen zu den logischen und semantischen Regeln korrekten Folgerns, ed. K. Jacobi, (Leiden: Brill, 1993), 195-212, p. 211.

${ }^{20} \mathrm{H}$. Hubien, Iohannis Bvridani: Tractatvs de Conseqventiis (Louvain: Publications Universitaires 1976), Book I c. 3.

${ }^{21}$ See Iohannis Bvridani: Tractatvs de Conseqventiis, Book I 9; and Buridan, Summulae de Practica Sophismatum, ed. F. Pironet (Brépols, 2004), Book 2 conclusion 14.

${ }^{22}$ D’Ors, 'Ex impossibili quodlibet sequitur (John Buridan)', p. 210.
} 
$p$ is impossible, 'not- $p$ ' is necessary. If we can show that necessary truths can be suppressed, that is, that $q$ follows from some premises $X$ if $q$ follows from $X$ and $r$, whenever $r$ is necessary, then it will follow that ' $p$ and not- $p$ ' follows from $p$ alone. But the proof of Suppression depends on ex impossibili quodlibet (and its converse, necessarium sequitur a quolibet): for either $q$ follows from $r$ alone, in which case $q$ is necessary (since $r$ is) and so $q$ follows from anything (including $X$ ); or not, in which case either $X$ is impossible, in which case anything follows from it (including $q$ ); or finally, $X$ is possible, in which case, either it is impossible to have $X$ without $q$, in which case $q$ follows from $X$, or not. But this last case, that it is possible for $X$ to stand together with the necessary truth $r$ without $q$, is ruled out by hypothesis. The argument is blatantly circular, and so the famous "Lewis proof" does not show that anything follows from an impossibility, and so does not defend the claim that a valid argument is one in which it is impossible for things to be as the premises signify without their also being as the conclusion signifies.

Lewis and Langford would be unmoved by this argument, for like many modern logicians, they identify necessary truths with tautologies and impossibility with the denial of tautology. ${ }^{23}$ But Buridan, like other medieval logicians, did not have such a restricted conception of logic. For them, not all valid arguments were formally valid, and they included materially valid arguments as worthy of the logician's notice. Buridan's definition of validity in terms of preservation of how things signify (things are as the conclusion signifies whenever they are as the premises signify - with the caveat already mentioned) includes not only the formally valid ("holding in all terms" as he puts it: i.e., preserved under uniform substitution) but also the materially valid, that is, analytic and enthymematic consequence. ${ }^{24}$ To support ex impossibili and ex falso inference in these cases, the Lewis argument is of no avail, as d'Ors observed.

\footnotetext{
${ }^{23}$ Lewis and Langford, Symbolic Logic, pp. 248-9.

${ }^{24}$ Iohannis Bvridani: Tractatvs de Conseqventiis, Book I c. 4.
} 
But d'Ors takes further objection to the Lewis argument. I have explained elsewhere how the final step of Disjunctive Syllogism is valid (relevantly) in rule form but not in thesis form (as it is in classical and intuitionistic logic). ${ }^{25}$ D'Ors finds this distinction in Domingo de Soto's Summulae ${ }^{26}$ he agrees that if both $p$ and 'not- $p$ or $q$ ' are asserted absolutely, that is, categorically, then $q$ can be inferred and asserted categorically too; but if $p$ and 'not- $p$ or $q$ ' are asserted only on assumption (as they are if each is inferred from one conjunct of ' $p$ and not- $p$ ', dialetheism aside) then to infer $q$ is no more valid than to infer, say, $q$ from $p$ by uniform substitution if $p$ was only assumed, not proved (categorically). That is exactly the diagnosis and rebuttal of Lewis' argument found in relevance logic. ${ }^{27}$

In point of fact, one does not need to appeal to Lewis' (and Langford's) argument, even if it were legitimate to do so (as d'Ors has disproved), to support the inference of an arbitrary proposition from an impossibility. For example, Burley appeals to the topic "from the less": 28

"Anything follows from the impossible and the necessary from anything ... For in both cases it is argued affirmatively through the topic 'from the less'. For it is less apparent that ... 'A man is an ass' is true than that 'Socrates runs' is true. And if what is less apparent exists, what is more apparent will exist. Therefore, if a man is an ass, 'Socrates runs' follows. This holds through the topic 'from the less'.

\footnotetext{
${ }^{25}$ Stephen Read, 'Formal and material consequence, disjunctive syllogism and gamma', in Argumentationstheorie, ed. Jacobi, 233-59, p. 253.

${ }^{26}$ D'Ors, 'Las Summulae de Domingo de Soto: Los limites de la regla «Tollendo ponens»', Anuario Filosofico 16 (1983), 209-17.

${ }^{27}$ See, e.g., Read, 'Formal and material consequence, disjunctive syllogism and gamma', pp. 235-7.

${ }^{28}$ Burley, On the Purity of the Art of Logic, tr. P.V. Spade (Yale UP, 2000), pp. 61-62.

29 “... ex impossibili sequitur quodlibet et necessarium sequitur ad quodlibet ... nam utrobique arguitur per locum a minore affirmative. Nam minus videtur, quod ... haec sit vera: 'Homo est
} 
Burley observes, however, that this argument might not allow one to infer anything whatever from the impossible: "for from the less impossible the more impossible does not follow." ${ }^{30}$ Thus he restricts himself to the claim that from the impossible anything less impossible, in particular, anything contingent, follows.

Let us come back to Kilvington's $47^{\text {th }}$ sophism and his objection to Burley's obligational rule ex falso: "when a false contingent proposition has been granted, one can prove any false proposition compatible with it." What Kilvington wants to propose is that there are cases, such as the sophism here, which should rather be doubted. To this end, he makes a salutary observation. It is clear that one often grants a false proposition in an obligational disputation-indeed, the subtlety of the game usually depends on the falsehood of the positum, at least according to the casus. Thus granting is different from truth and should not be confused with it. No more should denial be confused with falsehood: once again, one may be obliged to deny something one knows full well to be true. What Kilvington observes, and is much harder to grasp, is that doubting is different from being in doubt, that one may be obliged to express doubt about a propositum about which one is not in doubt at all. This is hard to see, since the obligational rules seem to require one to express doubt only about irrelevant propositions about which one does not know whether they are true or false-that are not specified by the casus, and those seem to be precisely the proposita about which one is in doubt. But this is to overlook the central point of the sophism, observed by d'Ors, that Kilvington rejects Burley's rules for replying to irrelevant proposita as inappropriate for discussing counterfactuals: not by proposing a different theory of obligations, but by setting aside those rules and

asinus', quam quod illa sit vera: 'Sortes currit', et si illud, quod minus videtur, sit, et illud, quod magis videtur, erit'; igitur: Si homo est asinus, sequitur: Sortes currit, et hoc per locum a minore." Burley, De Puritate Artis Logicae, ed. P. Boehner (St Bonaventure: The Franciscan Institute, 1955), Tractatus Brevior, p. 248.

30 “... quia ex minus impossibili non sequitur magis impossibile." (Ioc.cit.) 
proposing that one must express doubt about a propositum which Burley's rules would force one to grant.

The crucial passage is this (p. 132):

"In reply to the argument it must be granted that you know that the king is seated or you know that the king is not seated. But the assumed minor premise-viz, 'You do not know that the king is not seated'-must be doubted. For if the king is seated, you do not know that the king is not seated-by the hypothesis-and the antecedent must be doubted; therefore, the consequent must be doubted." ${ }^{31}$

If we granted the minor premise ('You do not know that the king is not seated'), the sophism ('You know the king is seated') would follow by Disjunctive Syllogism. But that is absurd, for we would then have shown that the king is seated simply from the casus (which does not specify whether the king is seated or not) and an instance of the law of excluded middle ('Either the king is seated or the king is not seated'), which is simply a law of logic and again does not specify which disjunct obtains. On the other hand, if we denied the minor premise, it would follow that you do know that the king is not seated, again determining whether he is seated. The only possibility is to express doubt about the propositum, even though you do know that you don't know that the king is not seated. Burley's rule for irrelevant truths (cited at line 3 of the proof of the sophism) must be rejected.

This rejection and revision is found a little earlier in Kilvington's discussion in the passage on which Kretzmann and Spade alight. Kilvington writes (p. 131):

\footnotetext{
31 "Ad argumentum concedendum est quod tu scis regem sedere vel tu scis regem non sedere. Sed minor coassumpta est dubitanda—scilicet, haec: 'Tu non scis regem non sedere'. Quia si rex sedet, tu non scis regem non sedere-per casum—et antecedens est dubitandum; igitur consequens est dubitandum." (p. 135)
} 
"And when it is argued, 'This is true and irrelevant; therefore, this must be granted', I reply that if one is speaking of what is irrelevant as that expression is commonly taken-for a proposition that neither follows from nor is incompatible with what has been posited or granted, and so on-this does not follow: ${ }^{32}$ 'This proposition is true and irrelevant; therefore it must be granted'. But if the term 'irrelevant' is taken for a proposition that is true now and that would not be true in virtue of its being in fact as is signified by the positum, then I say that the proposition '[You are not in Rome or you are a bishop]' is relevant ${ }^{33}$ to the positum-i.e., 'You are in Rome'. For if you were in Rome and you were not a bishop, this would have to be denied: 'YYou are not in Rome or you are a bishop]. .34

\footnotetext{
${ }^{32}$ The Kretzmanns write (p. 344): "[Kilvington] is rejecting [this rule] not as a rule applied to counterfactual reasoning generally but specifically as a rule of obligations." Not so: he is rejecting the obligational rule as unsuitable for the counterfactual reasoning needed in the sophism.

${ }^{33}$ The Kretzmanns have 'irrelevant' here. My emendation is supported by three mss and again, I believe, makes better sense. Perhaps the confusion here between pertinens and impertinens explains why many commentators are unsure whether Kilvington is giving a different criterion for being relevant or a different rule for how to respond to irrelevant propositions. See, e.g., Stump 'Roger Swyneshed's theory of obligations', Medioevo 7 (1981), 135-74, reprinted in her Dialectic and its Place in the Development of Medieval Logic (Cornell UP, 1989), pp. 228-9; Yrjönsuuri, Obligationes, pp. 121-2.

34 "Et quando arguitur 'Ista est vera et impertinens; igitur ista est concedenda', ad illud dico quod loquendo de impertinenti ut communiter sumitur-pro propositione non sequenti vel repugnanti posito vel concesso, et ita de aliis-[non] sequitur 'Haec propositio est vera et impertinens; igitur est concedenda'. Si tamen accipiatur iste terminus 'impertinens' pro propositione quae nunc est vera et quae non foret vera ex hoc quod ita foret ex parte rei sicut significatur per positum, tunc dico quod ista propositio '[Tu non es Romae vel tu es episcopus]' est [im]pertinens huic posito, quod est 'Tu es Romae'. Quia si tu esses Romae et non esses episcopus, hoc foret neganda: '[Tu non es Romae vel tu es episcopus]'." (p.134) As well as substituting Burley's first example for his second (which Kilvington cites here), I have also emended the Latin text following the apparatus given by the Kretzmanns, as in the English translation in the text.
} 
That is, the major premise is relevant to the positum, since its truth-value is affected by whether the positum is true, and would be false if the positum were true, i.e., if you were in Rome. Given that you are in Rome but not a bishop, it is false and should be denied.

Kilvington accordingly rejects the common way of treating irrelevant proposita: they should not be granted if they are true and denied if they are false, but should be granted if they would be true if the positum were true and likewise denied if they would be false. Thus the positum is relevant to their evaluation. Consequently, sophism 47 should be doubted. For given the casus, that if the king is seated you know it and if he is not you know that too, and given that you do not know whether the king is seated (as is common in obligations), you do not know whether you know that the king is seated:

"But it must be doubted whether the king is seated or is not seated, and it must be doubted whether you know that the king is seated ... And yet, although the proposition must be doubted by you, it must not be granted that the proposition 'The king is seated' is in doubt for you." (p. 131) 35

To sum up: early training in the logical art of obligations led to the terminology and practice of granting, denying and doubting becoming endemic in logical treatises. But Kilvington realised that the way irrelevant propositions are treated in obligations can lead to unwarranted inconsistencies when employed outside their natural home. This becomes dramatically clear once the classic argument for ex impossibili quodlibet, discovered in the $12^{\text {th }}$ century and made famous by Lewis and Langford in the $20^{\text {th }}$ century, was used by Burley to establish an ex falso rule in obligations: admitting any false positum commits the

\footnotetext{
35 "Sed dubitandum est utrum rex sedet vel no sedet, et ideo dubitandum est an tu scis regem sedere ... Et tamen, licet ista propositio sit dubitanda a te, non tamen est concedendum quod ista propositio 'Rex sedet' est tibi dubia." (p. 135)
} 
respondent to granting any other falsehood compatible with it. However, rather than proposing simply to revise the rule for irrelevant propositions, Kilvington is best understood, as argued by Angel d'Ors, as proposing to set aside the common practice of obligations and to realise that in reasoning about counterfactual situations one cannot separate relevant propositions from irrelevant in the usual way. For seemingly "irrelevant" propositions would take a different truth-value if things were as signified by the positum. Consequently, far from obligations having the aim of modelling counterfactual reasoning, as suggested by Kretzmann and Spade, they are inconsistent with that aim and unsuitable for its prosecution.

University of St Andrews, Scotland 